\title{
Peatlands and Plantations in Sumatra, Indonesia: Complex Realities for Resource Governance, Rural Development, and Climate Change Mitigation
}

\author{
Craig C. Thorburn and Christian A. Kull \\ Centre for Geography and Environmental Science \\ Monash University, Melbourne, Australia
}

This is an author pre-print version of:

Thorburn, CC \& CA Kull (2015) Peatlands and plantations in Sumatra, Indonesia: Complex realities for resource governance, rural development and climate change mitigation. Asia Pacific Viewpoint 56 (1):153-168. DOI: 10.1111/apv.12045.

The final definitive version is available through Wiley's Online Library

(http://onlinelibrary.wiley.com/doi/10.1111/apv.12045) or via http://dx.doi.org/10.1111/apv.12045

\begin{abstract}
Peatlands play a crucial role in Indonesia's economic development, and in its stated goal of reducing greenhouse gas emissions. Improved peatland management - including a national moratorium on the granting of any new conversion licenses - forms a cornerstone of Indonesia's climate change mitigation commitment. At the same time, rapid expansion of the plantation sector is driving wide-scale drainage and conversion of peat swamp ecosystems. The province of Riau, in central Sumatra, finds itself at the crossroads of these conflicting agendas. This essay presents a case study of three islands on Riau's east coast affected by industrial timber plantation concessions. It examines the divergent experiences, perceptions and responses of communities on the islands. A mix of dramatic protests, localised everyday actions and constructive dialogue has succeeded in delaying or perhaps halting one of the concessions, while negotiations and contestation with the other two continue. With the support of regional and national non-governmental organisations and local government, communities are pursuing alternative development strategies, including the cultivation of sago, which requires no peat drainage. While a powerful political economy of state and corporate actors shapes the contours of socio-environmental change, local social movements can alter trajectories of change, promoting incremental improvements and alternative pathways.
\end{abstract}

Keywords: Peatlands, Deforestation, Plantations, Pulp and Paper, Sago (Metroxylon), Acacia, Climate Change, Indonesia, Social movements, Political ecology

\section{Introduction}

Indonesia's peatlands are volatile crucibles. They mix carbon and biodiversity, water and fire, villagers and corporations, activists and managers. They are flashpoints for conflict over national economic development, climate change mitigation, and local governance. The Indonesian government's 2009 pledge to reduce greenhouse gas (GHG) emissions by $26 \%$ from a projected business-as-usual baseline by 2020 depends on the country's ability to curb deforestation, particularly on peatlands (DNPI 2011). Peatlands store massive amounts of carbon, which is released into the 
atmosphere through the drainage, biomass removal, decomposition and burning that accompanies logging and land conversion activities. Yet, such activities continue, despite a formal moratorium from the Indonesian government, protest and resistance from local communities, and legal challenges from civil society groups. In late 2011, for example, 28 demonstrators stitched their mouths shut in front of the national parliament building in a dramatic protest against the actions of a major pulp and paper company that had obtained a concession covering 40 per cent of a 100,000 hectare peat island in Riau province in central Sumatra.

Such resource conflicts are quintessentially 'political ecological': they revolve around dramatic changes to the environment and divergent impacts on different parts of society, caused by multi-scalar, historically and geographically particular processes. This particular conflict in Riau Province - which can be seen as a microcosm for the 'pulp, palm, and peat' triad around the country - is interesting in how its political ecology has played out. On the one hand, the growth and reach of industrial peatland exploitation is a stark reminder of the forceful logic of capitalism. On the other hand, as we shall point out, the different experiences on different islands in Riau Province show that local and regional activist networks defending local senses of justice and access to resources can have an impact.

This article presents a case study of peatlands on coastal district of Riau province. It seeks to understand the pressures that have underlain the dramatic transformation of this portion of Indonesia's environment, and asks why the outcomes - in terms of protest, governance, and plantation implementation - vary across three neighbouring islands. In doing so, we draw out broader conclusions for political ecology that support to three key precepts of the field. The first is a reminder of the inexorable pressure of capitalism viscerally manifested in the landscape, and the centrality of economic production and political processes in understanding particular environmental outcomes (Peet, Robbins and
Watts 2011). The second is the proposition that local resistance and activism do have impacts. As Rajan and Duncan (2013) point out, such actions can make incremental improvements to peoples' lives and environments. Third, an applied political ecology can help to identify alternative pathways and suggest better ways of managing these landscapes that are more environmentally sustainable and socially just.

\section{A Political Ecology Approach}

Scholars of environmental change have long investigated the impacts of large-scale industrial demand on landscapes and local communities. Early texts under the banner of political ecology were very much concerned with the role of natural resource-based industries in driving environmental transformations in particular regions (e.g. Hecht and Cockburn 1989; Peluso 1992). More recently the field has tended to emphasize other processes like conservation and control, resource management discourses, and environmental subjectivities (Robbins 2012). Peet et al. (2011: 23) argue for a return to political ecology's political economy roots: 'capitalism and its historical transformations is a starting point for any account of the destruction of nature'.

Given this renewed emphasis on powerful external driving forces, one can easily despair of making a difference, of protecting local lives and landscapes from big capital and/or the predatory state. However, social movements and protests occasionally succeed in curtailing the most brazen initiatives - such as the well-known cases of water privatization in Bolivia or Daewoo's land grab in Madagascar. Local communities, tapped into networks of NGOs and social movements, can make a difference.

It is important to bear in mind that such 'revolutions' are rare. Rajan and Duncan (2013), however, suggest that mid-scale social action can make incremental but meaningful differences. Building on the theories of Karl Polanyi (1957: 20), they argue that 'social change need not just be about large, 
transformational events recognizable as revolutionary, but can equally be about relatively localized everyday attempts to marginally improve the day-to-day drudgery of life'. They suggest that researchers pay more attention to 'movements for habitation' - attempts by society to 'protect itself against the forces that undermine its social solidarity and threaten to distort its relationship to the natural environment' (Polanyi 1957: 132). Following their line of argument, it makes sense to understand the development trajectories and environmental transformations of particular regions as coproduced - on varied terms depending on the particular power relationships - by local actors, social movements, major industries, and the state.

In Indonesia, there has been an active and vocal environmental NGO community since the 1980s (Peluso, Afiff and Rahman 2008). There is a growing consensus that NGOs and civil society groups are finally gaining traction in their long struggle for greater environmental justice and forest peoples' access rights and sustainable livelihoods. Sadly, little of this has found its way into international scholarly literature. Numerous studies in the post-Suharto era have focused on the perverse environmental impacts of decentralization and 'Reformasi' politics (e.g., Barr, Resosudarmo, Dermawan and McCarthy 2006; McCarthy and Moeliono 2011). Others emphasise opportunities for increased community engagement, rights and access (Colfer and Resosudarmo 2002; Thorburn 2002), and note some progress in community forestry and forest co-management (Campbell 2002; Djajanti 2006) .

This article hopes to make a small contribution to this literature, by examining the perceptions, responses and collective actions of local communities in defence of livelihoods, habitat and environment in the face of powerful state and corporate actors in one of the world's most rapidly deforesting regions. It suggests that while political economic forces strongly shape the contours of socio-environmental change, social movements can and do co-produce specific, grounded trajectories of change. The outcomes described here may not look like grand victories; they are more about making big changes less disruptive at the local level, and seeking alternative pathways.

The information used in the preparation of this article was gathered during three visits to Riau province in 2012-13. Initial briefings with national environmental and human rights NGOs and members of the National Forestry Council (Dewan Kehutanan Nasional, DKN) provided background material, while in Riau, the lead author was hosted by local NGOs, primarily the Riau chapter of the Indonesian national environmental forum (Walhi) and an affiliation of local community organisations under the collective banner of the 'Riau Peatland Communities Network' (Jaringan Masyarakat Gambut Riau, JMGR). These organisations provided introductions to provincial and district forestry and government officials and to communities on two of the affected islands. Local politicians and our NGO hosts both urged us not to attempt to visit the third island (Pulau Padang, see below), as they felt that the presence of foreign researchers could create suspicion and inflame tensions, which were running high throughout the period this research was undertaken. (They did manage to meet with a few people from that island while visiting the district capital.) The lead author stayed for several days in the district capital of Selat Panjang, and in villages on Tebing Tinggi and Rangsang islands, holding discussions with district government officials, former and current village government leaders, farmers, small business owners and youth groups, and also traveling around the perimeters of concessions to observe environmental conditions and meet people in their fields and homes. He was able to observe and participate in a number of community activities, including programs initiated by some local NGOs to map land use and village boundaries and survey the ecological health of forest ecosystems. Interviews and group discussions were largely unstructured and open-ended; everyone we met was anxious that their story be heard. Preliminary drafts of the descriptive and analytical material 
presented here were distributed to NGO and local government hosts for comments, feedback and corrections.

The first part of this paper examines the problem of peatland management at a variety of scales, from an abstract global concern to the geographic and historical particulars of the case study of the Meranti islands in Riau Province. We then present and compare the ongoing corporate 'acacia invasion' and local reactions to it across the three Meranti islands, illustrating the forcing power of capitalist exploitation at the same time highlighting local people's differing successes in 'movements for habitation'. We present sago cultivation as a more socially just and environmentally sustainable alternative pathway for communities and businesses in the Meranti islands.

\section{For Peat's Sake: Why Peat Forests Matter}

Peat is an accumulation of partially decomposed vegetation. Peat forms in wetland conditions, where waterlogging obstructs the flow of oxygen from the atmosphere preventing dead leaves and wood from fully decomposing. Peat wetlands perform a number of vital ecological functions, including regulating water flow and stabilising regional evaporation rates, supporting unique flora and fauna, and sequestering vast amounts of carbon in the organic matter trapped in waterlogged soil (Corlett 2009). Altogether, the world's 4 billion $\mathrm{km}^{2}$ of peatlands, scattered across 170 countries, contain between 180 and 455 billion metric tons of sequestered carbon (Page, Rieley and Banks 2011). Over geological periods of time, peat turns into lignite coal, accumulating at a rate of about one millimetre per year (Andriesse 1988). In cool climate regions like Ireland and Finland, peat has long been exploited as source of fuel. Dried peat is classified by the UN as a non-renewable fossil fuel with similar greenhouse gas emission characteristics to coal (WCED 1987).

Tropical peat swamp forests are a particularly challenging environment for humans. Throughout most of human history they have been left largely undisturbed, beyond the subsistence activities of small indigenous communities (Page et al. 2011). Yet beginning in the $1980 \mathrm{~s}$ and accelerating through subsequent decades, the peat swamp forests of places like Sumatra, Borneo and New Guinea have been subjected to extensive logging, drainage, plantation development and landscape fragmentation by smallholder farms. These changes can be attributed to the depletion of forests in mineral soil areas and continuously rising demand for forest and agricultural products (Miettinen, Shi and Liew 2012).

Conversion of peatland to other uses releases carbon into the atmosphere, through removal of aboveground biomass, fires, and decomposition of the peat as a consequence of draining. Drained peatland areas are extremely fire-prone. Even without fire, peat oxidizes when exposed to the atmosphere, releasing $\mathrm{CO}_{2}$. Converting peatlands to other land uses transforms these areas from carbon sinks into major carbon emitters. Globally, $\mathrm{CO}_{2}$ emissions from drained peatlands amount to two gigatonnes per year, representing nearly 25 per cent of the $\mathrm{CO}_{2}$ emissions from the land use, land use change and forestry (LULUCF) sector (Joosten, TapioBiström and Tol 2012). A further consequence of peatland conversion is threats to biodiversity, as peat swamp forests have become important refuges for endangered species such as the orangutan, tiger and elephant, already threatened by widespread deforestation elsewhere (Miettinen et al. 2012).

Peat poses problems for both engineers and agriculturalists. Peat is highly compressible under even small loads, making construction of roads and structures difficult. Tropical peat soils are highly acidic, with $\mathrm{pH}$ ranging between 3 and 4.5. As it dries, the physical and chemical properties of peat change, causing it to become hydrophobic. This phenomenon of irreversible drying makes peat soils unsuitable for shallow-rooted annual crops. Drainage causes peat soils to subside, initially from shrinkage as pores collapse and solid materials compress, then 
continuing as the carbonaceous materials oxidise (Joosten et al. 2012).

Tropical peatlands account for 11 per cent of global peatland area, but contain 20 per cent of global peat carbon - with 77 per cent of that amount located in Southeast Asia (Hooijer et al. 2010). More than half of the world's tropical peat swamp forests are located in insular Southeast Asia (Miettinen et al. 2012). Peat fires and decomposition are the primary reason that Indonesia now ranks third in the world (after China and the United States) in greenhouse gas emissions, contributing approximately 5 per cent of the global total in 2005 and projected to increase significantly through the 2020s (DNPI 2011). The locus of Indonesia's deforestation and biodiversity loss has now shifted primarily to peat wetland zones (Miettinen et al. 2012).

The major driver behind peat forest conversion is large scale plantation development (Casson 2002; Koh and Wilcove 2008; Miettinen et al. 2012). Developers dig canals to drain the peat sufficiently to allow access to heavy machinery to remove the trees, which are used to provide raw material for the timber and pulp and paper industries. This is usually followed by conversion into oil palm (Elaeis guineensis) and fast-growing pulpwood (mainly Acacia crassicarpa) plantations. In fact, peat is not well suited for oil palm; subsidence can cause large numbers of palms to topple after about four years, about the time they come into full production. Both oil palm and pulpwood plantations are continuously drained to keep the water table below the trees' root systems.

In support of Indonesia's commitment to reduce greenhouse gas emissions by 26 per cent, in May 2011, Indonesian President Yudhoyono enacted a moratorium on new concession licenses to clear or convert primary natural forests or peat lands greater than three meters in depth to agricultural or other uses (Government of Indonesia 2011). The moratorium was extended for an additional two years in 2013.

\section{Riau: Province of Peat, Oil Palm, and Pulp}

The province of Riau in central Sumatra holds the largest stores of peat in Indonesia. Papua's and Central Kalimantan's peat swamps are vaster in terms of overall area, however Riau's peat deposits - some over 10 meters deep - contain an estimated 16.4 gigatons of carbon, nearly a quarter of Indonesia's total (Uryu et al. 2008). Riau has experienced some of the most rapid and extensive deforestation in Indonesia, with total forest area declining by 65 per cent in the past quarter century. Riau's peat forest cover has declined from 80 per cent in 1990 to just over 36 per cent in 2010 (Jauhiainen, Hooijer and Page 2012).

As in other areas across the region, the primary driver of peatland conversion has been oil palm plantation development. Riau has been at the epicentre of this growth, leading the country in plantation establishment through the 1980s and '90s (Uryu et al. 2008). More recently, oil palm expansion has spread to other parts of the country, while the primary force behind forest conversion in Riau has shifted to fast-growing acacia plantations for pulp and paper manufacture (Jauhiainen et al. 2012).

The distribution of pulpwood plantations is dependent on the location of pulp mills, which require far larger investments than the infrastructure necessary for palm oil processing. Riau is home to two of the world's largest pulp mills, one operated by Asia Pulp and Paper (APP), and the other by Asia Pacific Resources International Limited (APRIL). These two mills produce more than two-thirds of Indonesia's total pulp output, each with a capacity of over 2 million tons per year. Between them, these two companies hold industrial forest concession (Hutan Tanaman Industri, or HTI) rights to approximately 25 per cent of Riau's total land area. Around 75 per cent of APP's pulp plantation land and 45 per cent of APRIL's is located on peatland (Uryu et al. 2008).

Pulpwood plantations take seven years to come into production; much of the more than 
Figure 1: Location of the plantation concessions on the Meranti Islands, Riau Province, Sumatra, Indonesia.

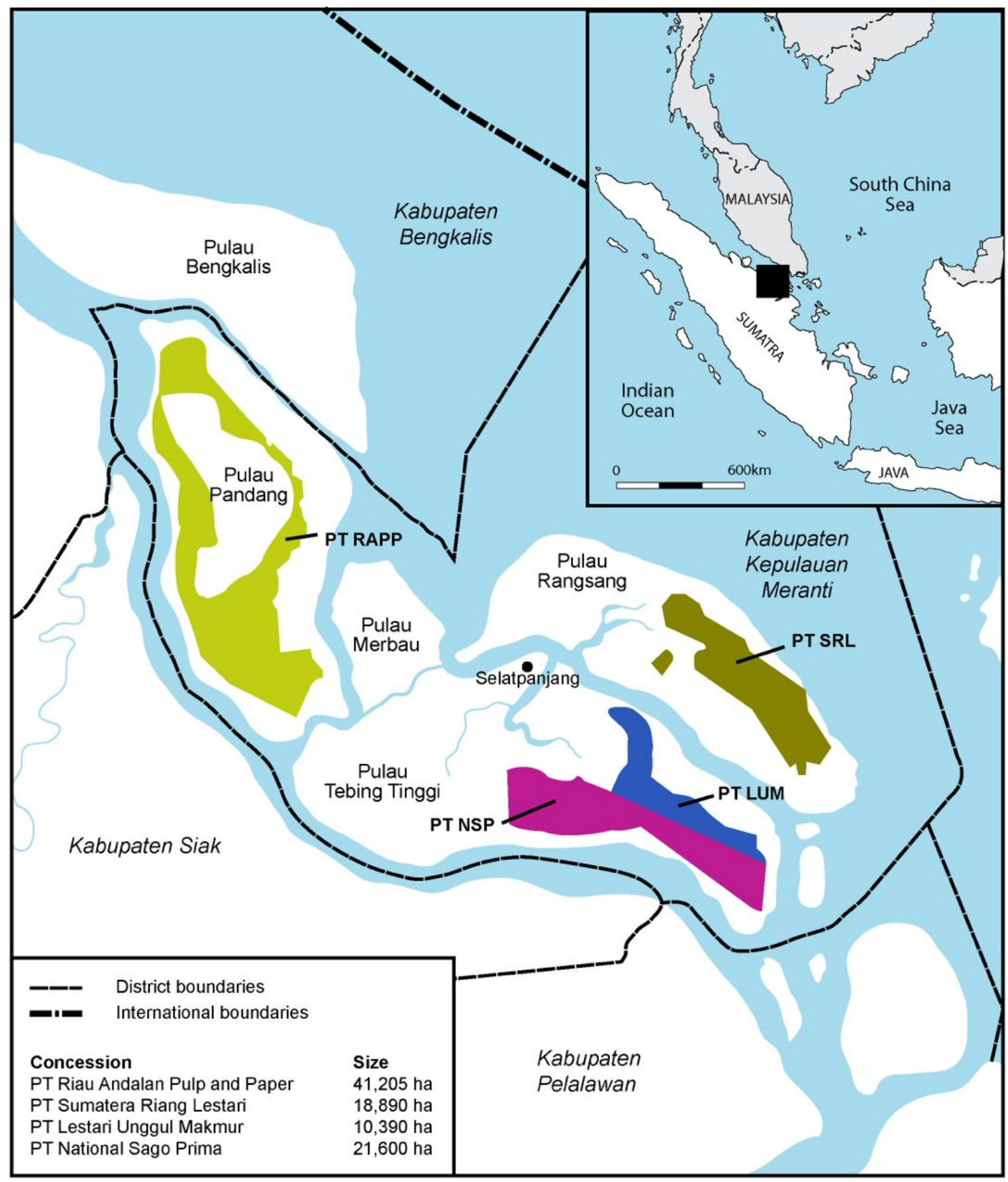


10 million cubic meters of wood used each year to feed these mills currently comes from land clearance for new plantations, and, according to numerous allegations, from illegal logging (Barr, Dermawan, Purnomo and Komarudin 2010).

The APRIL mill, PT Riau Andalan Pulp and Paper (RAPP), is the larger of the two, and commenced operations nearly a decade after APP's Indah Kiat mill. APP has more HTI concessions than its rival, a situation that the Forestry Ministry sought to address in 2009 with a controversial decision to grant an additional 350,000 hectares of HTI concession rights across five districts in Riau, to RAPP (Ministry of Forestry 2009). Local NGOs have challenged the legality of this decision, pointing out numerous legal and administrative flaws in the environmental impact analysis and recommendation processes, while noting that many of the concessions are situated on deep peat (TP2SK 2010).

\section{Kepulauan Meranti: Sinking Islands at Indonesia's Edge}

The district of Kepulauan Meranti (the Meranti Islands) on the east coast of Riau Province represents a microcosm of the peatpulp-climate-livelihoods nexus in Indonesia. Events unfolding there illustrate the challenges Indonesia faces as it attempts to grow its economy while achieving greenhouse gas reduction targets. Like thousands of other small low-lying islands across the archipelago, communities on the Meranti islands are seriously threatened by the consequences of sea level rise. Paradoxically, the national government's economic development plans for the islands contribute to the problem in two significant ways. Draining the peat domes in the islands' centres accelerates the subsidence process already underway from decades of legal and illegal logging and smallholder agriculture, while also increasing overall GHG output - i.e., Indonesia's contribution to global climate change and sea level rise.
Before describing the different ways in which the conflicts over the pulp plantations have unfolded on the Meranti Islands, we first establish the historical and geographical context. The four main islands cover an area of just over $3,700 \mathrm{~km}^{2}$ (Figure 1). The islands' highest point - the peat dome located in the centre of Pulau Padang - is a mere seven metres above sea level. Nearly all the land is peat swamp, with small deposits of clay soil along tidal rivers. According to the Ministry of Forestry, the islands are comprised entirely of state forestland, although official gazettement as state forests is yet to take place.

Just over 175,000 people live in Kepulauan Meranti. The district government's spatial plan calls for approximately 30 per cent of the islands' total area - much of the coastal zone of the four main islands - to be excised from the national forest estate (Kabupaten Kepulauan Meranti 2013).

The history of human habitation on the islands dates back only about one hundred years. The vast swamp and mangrove forests of Sumatra's eastern coast presented a harsh environment that even traditional orang asli hunters and gatherers mostly avoided (Barnard 2003). During the pre-modern period this coast was largely uninhabited; settlements tended to cling to riverbanks many kilometres upriver, where alluvial deposits allowed for some agriculture.

For centuries, Eastern Sumatra's fine and abundant timber, including camphor, medang and merbau, was exported to ports throughout the region for use in ship construction and repair (Barnard 2003). The importance of the region's timber trade increased during the $19^{\text {th }}$ century as teak producing regions became deforested. In the 1850s, the Sultan of Johore began granting rights to Singapore firms to harvest timber in the region. These timber operations, known as panglong (a Hakka word meaning 'plank storage place'), formed the first semipermanent settlements on the Meranti Islands. The port of Selat Panjang, now the district capital of Kepulauan Meranti, was established during this period (Ukirsari 2012). 
Panglong owners' trade expanded to include charcoal and firewood cut from coastal mangrove forests, and sago starch extracted from the Metroxylon palm (Vleming 1992).

By the 1880s and ' 90 s, penghulu (headmen) of various negeri (autonomous settlements) from the eastern Sumatran sultanate of Siak were granting rights to establish gardens along the coasts where slightly elevated areas allowed cultivation of tree crops. These early gardens mainly grew areca nut palm, later accompanied by coconut and rubber. These pioneer farmers did not initially establish permanent settlements, but eventually began building houses and bringing families. The origins of the 73 villages on the Meranti islands date back to this period.

This pattern of exploitation - selective logging of mangroves and large hardwood trees, and land clearing for smallholder areca, coconut and rubber groves, invariably leads to subsidence of the peat soils and increased saltwater intrusion. Landholders cut channels to drain the top layers of peat, piling the muck next to the channel to form a dry pathway. As peat dries, the process of subsidence begins, and will not stop until it reaches the water table level and equilibrium is re-established. Older rubber and coconut stands are notable by the height of the root structures protruding above ground, often a metre or more above the current ground level. Many older trees topple over, or die as a result of saltwater intrusion. Gardens and groves - and eventually settlements - have shifted inland as the coastal zone becomes untenable. Nearly all villages in the islands have had to abandon their original locations. Inhabitants can still show the foundation stones of the earlier settlements; these moves have occurred during the lifetimes of many people now living there.

Land use transformation accelerated in the 1980s and 90s, when a number of logging concession (Hak Penebangan Hutan, or HPH) permits were granted in the islands. Concessionaires practiced selective logging, taking only the largest and most valuable trees. They dug canals to transport the logs out of the interior, which often became permanent drains, leading to peat dehydration and increased fire danger. Local villagers used these canals to transport additional timber out of the interior, both for their own use and for sale. As occurred elsewhere, villagers also used logged-over areas to establish new rubber, coconut and sago groves. In the Meranti islands, this was a fairly orderly process, with village councils determining allocations, and some village government issuing land use permits. The choice of crop was determined by the land's elevation and hydrology; drier areas were planted in rubber or coconut, swampy areas with sago.

An expanding network of canals and pathways, including narrow concrete roadways to support motorbike and small cart traffic, extended outward from villages as more land was brought under cultivation. The twinned processes of land subsidence and saltwater intrusion have continued apace. The government has constructed tide gates in some channels to allow drainage while keeping seawater out, however these generally last a short time before falling into disrepair.

\section{The Sago Industry in Kepulauan Meranti}

As previously discussed, political ecology focuses on the ways particular political and economic systems and modes of resource access combine to shape the trajectories of particular environmental problems. Political ecology is increasingly called upon to identify ways to resolve these problems. An important task of engaged political ecology is to seek to understand the ways that individuals, households and communities cope with change, organise for survival, and unite for collective action. These knowledges, practices and strategies can become part of alternative development strategies (Robbins 2012).

Fieldwork in the Meranti islands brought to light one such opportunity. Prior to the arrival of HPH logging concessions in the 1990s and $\mathrm{HTI}$ industrial pulp plantation concessions in the 2000s, villagers and entrepreneurs in the 
Meranti Islands were already pursuing a natural resource-based livelihood and industry that can produce very different social and environmental outcomes.

The large islands and coastal lowlands of eastern Sumatra are ideal for sago production. The Metroxylon palm thrives in a swampy environment, requiring no drainage (Ruddle, Johnson, Townsend and Rees 1978). Therefore, unlike other tree crops currently being promoted on converted peat forest land, sago cultivation does not result in peatland subsidence.

The trade in sago in this region dates back hundreds of years. Sago is not indigenous to Sumatra or peninsular Malaysia; it was introduced by ancient seafarers sometime in the distant past (Tan 1983). 'Siak sago' has long been regarded as the highest quality; $15^{\text {th }}$ and $16^{\text {th }}$ century Chinese annals note its importance in the region (Barnard 2003). In the $19^{\text {th }}$ and early $20^{\text {th }}$ centuries it was traded by English and Dutch merchants for use as sizing in the textile industry. Today, nearly all sago produced here is shipped to Cirebon, West Java, for the manufacture of sohun glass noodles.

The sago palm multiplies vegetatively by stolons growing from the base of the trunk, forming dense stands and can become the dominant plant across vast areas of swampland (McClatchey, Manner and Elevitch 2006). It is easily propagated by separating suckers for replanting, and takes between seven to ten years to reach maturity. As mature stems are harvested, others replace them. An individual tree can reach ten meters in height and produce over $200 \mathrm{~kg}$ of pure starch. A well-managed sago garden can yield 150 stems per hectare per year, or approximately 30 tons of pure sago starch. As such, sago is a more productive plant than rice, in terms of both its output per area and labour input (Ruddle et al. 1978).

Sago is harvested by cutting the tree then splitting or peeling the trunk to expose the inner core. In many traditional societies, the sago is processed on the spot. In the Meranti islands and other regions with (semi)mechanised processing, the trunk is cut into meter-long pieces that can be rolled out of the forest and floated down rivers. To extract the starch, the pith of the core is scraped and pounded (or mechanically pulverized), reducing the fibre to small pieces and loosening the starch particles. The pounded/pulverized pith is then mixed with water and run through a filter into a settling vessel. The starch settles forming a thick paste, which is removed and further dried before packaging into moist cakes or sacks. Sago in this form is used to produce a variety of traditional dishes, as well as commercial products such as pearl sago, flour and noodles. An early industrial innovation was the introduction of simple forced-air ovens to dry the paste into fine flour that can be more easily transported and stored for longer periods without oxidizing or putrefying.

Most villagers in the Meranti islands grow a few stands of sago, which they harvest for use as a breakfast food or snacks, and sell some to local mills. In the mid-1980s, sago cultivation on the islands expanded after the national government tried to promote rice cultivation as part of the national rice intensification program. After a few seasons, most villagers elected to plant sago instead. Only about 1,500 hectares of rain-fed rice is currently grown on the islands, while some 7,000 households cultivate nearly 40,000 hectares of sago groves. Sago is Kepualuan Meranti's major crop: nearly 200,000 tons per year, compared to 22,000 tons of coconuts, 8,500 tons of rubber and 5,500 tons of rice.

For several decades, the sago trade in the Meranti Islands has been dominated by 60 or so mechanised mills operated mainly by Chinese tauke, many of these descendants of original panglong entrepreneurs. Diesel engines power a variety of machines to pulverise, mix, wash and strain the sago pith, and the paste is harvested from large settling ponds. These factories also include drying ovens, used to process the semisolid cake into sago flour. Each factory employs between 30 to 50 men - thereby forming the economic mainstay of neighbouring villages - and 
produce between 150 to 300 tons of dry sago per month. The mills lack waste treatment facilities; liquid effluent flows directly into streams or the strait, while the fibrous pith is dumped in fetid heaps. The sago bark is usually piled in a crosshatch manner along the shoreline to build up a bank and counter subsidence and erosion. Most of these operations own several hectares of sago gardens, and also purchase additional sago trunks from villagers.

In the late 1980s, the national Inpres Village Development Program provided four miniature mills to process villagers' sago in the Tebing Tinggi subdistrict. A small diesel engine drives a rotary rasp to shred the sago pith and a small propeller located in a mixing vat. These simple mills are capable of processing between 10 to 20 sago trunks per day, producing between 20 and 30 tons of wet sago per fortnight. Each mill provides part-time employment for about ten people. A number of local entrepreneurs soon constructed their own mills; presently there are 17 'sago rakyat' mills operating in Tebing Tinggi. Profits are slim, particularly with rising fuel costs. The sago cake produced by these mills is of inferior quality, still containing some fibre and impurities. Their entire production is purchased by a sole trader operating from Selat Panjang, who often has difficulty collecting enough sago to fill his 150-ton boat for a fortnightly trip to Malaysia.

The Indonesian government has long been interested in developing sago's economic and food security potential, categorising sago as a strategic national food crop. Sago is receiving renewed attention as a possible response to climate change, which is expected to adversely impact rice production in Indonesia and elsewhere (Alfons and Rivaie 2011). The government of Kepulauan Meranti is promoting sago as a primary engine of growth and prosperity in the district, and plans to more than double the area in the district under sago cultivation, to over 100,000 hectares with a projected annual production of 400,000 tons of sago flour. A commercial sago plantation has recently begun operations on a former timber concession in the Tebing
Tinggi Timur subdistrict (see below). Presently, demand exceeds production, and there has been a raft of sago theft, targeting harvested trunk sections awaiting transport to mills, and stolons for sale to the plantation. According to many growers, however, the greatest threat to sago production in Kepulauan Meranti is alteration of the islands' hydrology resulting from the establishment of pulpwood plantations.

\section{The 'Acacia Invasion' and Local Movements for Habitation}

Since 2007, the Ministry of Forestry has issued HTI concession permits for three acacia plantations on the islands to companies affiliated with APRIL/RAPP (Figure 1). The permits were issued before Kepulauan Meranti was split off from the much larger district of Bengkalis in 2009. Since the new district's establishment, the community and government have been embroiled in controversy over the three concessions. These cases, each reflecting differences in governance, networks and historical contingency, demonstrate how local 'movements for habitation' (Rajan and Duncan 2011) can sometimes attenuate the starkest impacts of industrial exploitation.

\section{The PT RAPP Concession on Pulau Padang}

The largest and most controversial of the HTI concessions in Kepulauan Meranti is PT RAPP on Pulau Padang. The 41,205 hectare concession covers nearly 40 per cent of Pulau Padang's total area, and borders all 14 villages on the island. Local activists claim that the concession area encompasses villagers' ancestral land, and that the land clearing and drainage will cause immense harm to the island's environment (Metroterkini.com 2013).

The concession stretches nearly the entire 60kilometre length of the island. A section of high conservation value forest on a peat dome is excised from its centre, leaving an elongated donut-shaped plantation (see map). Of the 41 thousand hectares, about two thirds $(27,775$ hectares) is to be planted in acacia, 
with the remainder set aside for timber species, 'livelihood plants', company facilities, and one 'non-productive area' where a petroleum company operates.

During 2009 and 2010, PT RAPP secured letters from the Village Heads of 11 of 14 villages on the island approving the concession's operation, claiming that the company will provide hundreds of jobs, new and improved roads, social and educational programs, and support for agricultural and small enterprise development. Three villages located in the south of the island rejected the concession altogether, and between 2010 and 2012, the Village Councils (BPD) of eight of the eleven 'pro-concession' villages also issued letters rejecting the concession. There began a series of increasingly impassioned public protests, at the site, in the district capital Selat Panjang, in the provincial capital Pekanbaru, and in Jakarta (Kompas.com 2011).

The district government initially supported the communities' wishes, dispatching three letters to the Ministry of Forestry requesting that all three HTI concessions in the district be reviewed. However, after the Director General of Forest Production responded in November 2010 that the concessions were legal and would go ahead, the district government has been left with little recourse other than attempt to implement the law, which has drawn it into conflict with groups opposing the RAPP concession.

The most outspoken segment of the opposition is supported and coordinated by Serikat Tani Riau (STR), the provincial branch of the National Farmers' Union (Serikat Tani Nasional, STN), which is affiliated with the Democratic People's Party (Partai Rakyat Demokratik, or PRD). STR promotes mass mobilisation, frequently organising marches, tent cities, 'open seminars', Istighotsah mass prayer meetings, and hunger strikes demanding that the RAPP concession be withdrawn. Angry crowds have disrupted 'socialization' events organised by RAPP, blockaded docks to prevent equipment being offloaded, and jostled and thrown water on visiting government officials.
PT RAPP began operations in March 2011, amid escalating tensions. The company rapidly dug several kilometres of drainage canals, cleared nearly 6,000 hectares of forest, and planted over one thousand hectares of acacia. Numerous demonstrators were arrested and detained, and a climate of fear and intimidation prevailed. Violence broke out at the site in July 2011; two RAPP excavators were burned and an operator killed. In late 2011, demonstrators set up an 'operations post' outside the provincial parliament building, and five demonstrators sewed their mouths shut in a dramatic protest gesture. In December, a delegation of 82 activists travelled to Jakarta, planning to sew their mouths and camp in front of the national parliament building. Not long thereafter, another six demonstrators announced their intention to self-immolate if the concession was not revoked. Twenty-eight people had stitched their mouths shut by the time the Minister of Forestry ordered RAPP to temporarily suspend operations in December 2011, and dispatched a mediation team to investigate the situation and propose solutions (Andiko et al. 2011).

The mediation team submitted their findings in January 2012, and the Minister offered that the land of the three villages in the south of the island that reject the concession be excised from the concession, effectively halving its size. The compromise further stipulated that all community lands would be mapped, with existing groves and farmland to be 'enclaved'. Hard-line opponents in Pulau Padang rejected this compromise, continuing to demand that the entire concession be cancelled. Individuals favouring conciliation claim to have been threatened and intimidated; some who we met in Selat Panjang claimed they were afraid to return to their homes on the island.

Nearly two years after being ordered to suspend its activities, in October 2013 PT RAPP, with the approval of the Ministry of Forestry, attempted to reinitiate land-clearing and planting on Pulau Padang. Protesters immediately launched an armada of small craft to prevent the company from landing its 
equipment. Police turned out in force - not to enforce the Ministry of Forestry's permit, but to prevent violence and encourage the two sides to negotiate. These negotiations were inconclusive, until eventually the company withdrew its barges (Berdikari.com 2013). For now, the impasse continues.

If PT RAPP's concession is revoked, the government will be required under Indonesian law to compensate the company. Meanwhile, PT RAPP's management continues to insist that they have done nothing wrong, that the environmental impact assessment and permit process were all conducted in accordance with Indonesian law. On its website, RAPP's parent company APRIL maintains that they are 'a leader in Asia in applying best practice sustainable forestry management', and 'part of the solution to the challenge of balancing environmental conservation, social and economic development' (APRIL n.d.).

\section{The PT SRL Concession on Pulau Rangsang}

A second permit was issued to PT Sumatra Riang Lestari (SRL), another APRIL/RAPP affiliate, for an 18,890 hectare HTI concession on Pulau Rangsang. Local communities there were not so unanimous or coordinated in their response, and the company was able to secure support letters from all of the neighbouring village governments. Canal and road construction, timber harvesting and forest clearance, and acacia plantation activities have proceeded at a rapid pace since late 2009. Four years on, over half the concession area has already been planted in acacia.

Villagers we encountered in neighbouring communities are fearful and confused. They claimed that there is little or no clarity about concession boundaries, about who will receive how much compensation, or about the location of or access to the five per cent of the concession area set aside for 'livelihood plants' for local communities. As such, the SRL case is the one that most closely adheres to a 'business as usual' model, resembling scenarios that played out across Indonesia's outer islands throughout the HPH timber concession era of the 1970s and '80s, the height of Indonesia's logging boom (Gillis 1988).

Villagers note with alarm that the local hydrology is changing;. Inundation is a regular feature of life for people living in peat ecosystems, however, this used to occur in a predictable, seasonal rhythm. Now, villagers we met explained that after just a few days without rain the canals from which they draw their water are reduced to a trickle, but just one night of rain and their yards and gardens are completely under water.

Any changes that occur, locals are quick to blame the acacia plantation. In 2012, the subdistrict seat of Tanjung Samak experienced its first cases of dengue fever; most people believe this is somehow related to the HTI concession. Coconut groves are infested with beetles; local farmers are certain that these and other pests have been forced out of the diminishing forest. As one villager explained:

'The beetles are angry since the concession took away their food. Now they attack our coconut trees. Maybe we'll get angry too, like those people in Pulau Padang. But who will we attack? Where will we get our food?'

PT SRL has several other HTI concessions throughout Riau province, and many of these have encountered concerted opposition and protest from local communities and NGOs. Perhaps anticipating greater resistance in Pulau Rangsang, the company has publicised numerous initiatives to underscore their commitment to local communities and the environment. These include articles in local newspapers about agreements with nine villages to grow 2,000 hectares of 'livelihood plants' (which they are legally obliged to do), efforts to protect the island's coastline through mangrove reforestation, and statements that the canals they are constructing are intended for hydrological management and fire suppression, thus 
potentially staving off disaster for island residents.

At the time of our visit in late 2012, the situation in Pulau Rangsang was becoming increasingly tense. Community leaders expressed concern that the sort of intimidation and violence that has plagued Pulau Padang might spread to Pulau Rangsang. If any sort of coordinated protest does eventuate, however, it will be too late to stop the plantation, which is nearly completely cleared and replanted. Communities can still organise around issues of compensation, access to livelihood plant zones, and watershed management, but to date, no-one is taking a lead role in such an endeavour.

\section{The PT LUM Concession on Pulau Tebing Tinggi}

The third case study contrasts with both of the previous ones. It can be characterized as constructive and cordial opposition that has succeeded (so far) in preventing the company from operating. It involves the first of the pulp plantation concessions on the Meranti islands, issued in 2007, to PT Lestari Unggul Makmur (PT LUM, another RAPP/APRIL affiliate), for a 10,390 hectare HTI concession on Pulau Tebing Tinggi.

The community of Sungai Tohor, the oldest and largest village in the subdistrict, had previously engaged in serious protests against PT Uni Seraya, a timber concessionaire that had formerly operated in the area. These actions included the torching of a logging camp and the house of the former Village Head in 2002 to protest damage caused to community members' rubber and sago groves. A number of villagers served prison sentences for their role in the violence.

Anxious to avoid a repeat of that previous experience, the community was more measured in its response to the arrival of PT LUM five years later. They quickly dispatched letters from Village Heads and Councils (BPD) of all seven villages bordering the concession area to district, provincial and national government officials, organised numerous (peaceful) demonstrations at the village and district levels, and sought support and guidance from environmental NGOs in the provincial capital Pekanbaru. The NGO website 'Eyes on the Forest' (2010) published an investigative report challenging the legality of the concession, pointing out that a significant portion of the concession area contained natural forest still in good condition, and noting as well that the concession area impinged on community members' rubber and sago groves.

Despite these protests, PT LUM initiated activities in 2008, cutting over 10 kilometres of canals and submitting an annual work plan (RKT) to the Forestry Ministry in 2009 to clear 2,832 hectares and remove over 260,000 cubic meters of wood. The company more-orless ceased operations soon thereafter however, and since 2009 have neither removed any wood nor cleared any land, although they continue to submit RKT work plans to the Ministry, and send out crews at least once each year to erect new boundary markers or make small modifications to existing canals. They need to do this to keep the concession license from being revoked for inactivity.

Villagers across Tebing Tinggi Timur, meanwhile, are engaged in a coordinated crusade to convert more land into rubber or sago groves - including the issuing of land use permits by village governments. With the Subdistrict Head (Camat)'s official blessing, each village is undertaking participatory mapping of their boundaries and land use with the assistance of a local NGO. Their strategy is to demand that this land be excised from the concession area, eventually diminishing its size to the point that it will not be worth PT LUM's effort to clear and plant acacia on the remainder. They are also attempting to position themselves as responsible environmental stewards.

Together with provincial environmental NGOs and a few concerned academics, community leaders in Sungai Tohor have established a young farmers association and a number of demonstration plots to encourage agricultural diversification; conducted training courses in 
forest surveying techniques; and established nurseries to support afforestation and enrichment planting programs. They plan to establish Sungai Tohor as a 'Centre for Sustainable Peatland Agricultural and Horticultural Development' to support the efforts of the Riau Peatland Community Network (Jaringan Masyarakat Gambut Riau, JMGR). In early 2013, a workshop of local villagers, village and subdistrict government leaders produced a 'Memorandum of Understanding' (Nota Kesepahaman) outlining shared goals for community-based management of forests on the island that emphasised active community participation; transparency; resolution of outstanding conflicts; improved community livelihoods and environmental conservation; and certainty of land use and boundaries established through a consultative process.

Unlike the protesters in Pulau Padang, community leaders in Tebing Tinggi Timur have cultivated cordial relations with district government officials, frequently hosting exhibitions, fairs, ceremonies and celebrations. The following conversation embodies the strategy they are pursuing:

'We need to avoid 'playing hard' like those people in Pulau Padang; look what it has gotten them...

'But the people there have been compelled by circumstances to do what they did. The company and the government have just forced their way.

'Yes, well we cannot let it come to that. We all lose when it becomes violent.'

The district government, for its part, has repeatedly petitioned the Ministry of Forestry to review, revise or revoke PT LUM's concession in Tebing Tinggi Timur. They point out that the concession has been inactive for four years, and recommend that it be converted either to a 'community forest concession' (Hutan Tanaman Rakyat, HTR), or perhaps a sago concession (see below).
These three case studies illustrate in different ways how local leaders and activists have reacted to the powerful, well-connected capitalist forces seeking to convert peatlands on their islands for acacia plantations. While communities in Pulau Rangsang were perhaps too slow or disunified to stop the company's actions or extract any concessions, in both Pulau Padang and Tebing Tinggi leaders and activists have so far succeeded in slowing or halting the concession activities. Each of these has taken a somewhat different approach, however, with the former emphasizing confrontational protest and the latter more constructive dialogue. In Pulau Padang, protesters demand nothing short of a total withdrawal of the concession. The national, and by most indications, district government's response has been to propose a mediated settlement involving compromise, but failing that, will back the concession as legal and supporting national and regional development objectives. The case of Tebing Tinggi Timur presents an alternative scenario that appears to stand the best chance of producing different forms of local development and alternative economic strategies, akin to the 'movement for habitation' propounded by Rajan and Duncan (2013).

\section{A New Type of Industrial Forest Concession}

Before concluding, we introduce another, new form of large-scale capitalist plantation development taking shape on the islands. In the southeast of Pulau Tebing Tinggi, adjacent to the inactive PT LUM concession, agribusiness giant PT Sampoerna Agro is developing Indonesia's first non-wood product industrial forest concession, to produce sago. The area is a former logging concession that was aggressively harvested during the 1990s by PT National Timber and Forest Products (NTFP). After harvesting most of the available timber, NTFP management began planting sago in logged-over wetlands. They eventually planted around 4,000 hectares, much of which is now reaching maturity. Since then, the concession has changed hands a few times, most recently 
when PT Sampoerna Agro purchased the rights in 2010 to form PT National Sago Prima (NSP).

NSP has already planted an additional 4,000 hectares of sago, and established a nursery to produce 380,000 seedlings needed each year. Eventually, 14,600 of the concession's 21,600 hectare area will be planted in sago; with the remainder consisting of 'livelihood plants' (most likely sago as well) for local communities, timber species, conservation forest, and a buffer zone between their concession and the neighbouring PT LUM concession. The company has already dug 170 kilometres of canals to control water levels and facilitate transport of harvested sago. NSP has constructed a modern processing facility with the capacity to produce 33 thousand tons per annum of high quality sago flour. The company's engineers are experimenting with using sago waste to run the factory's boilers. Sampoerna Biofuels, another subsidiary of the Sampoerna Group, plans to explore the possibility of utilising sago to produce biofuel (Jakarta Globe 2010).

The concession employs around 300 workers, with much of the low-skilled labour drawn from neighbouring villages. The company aims to source all of its sago from its own plantation, but has resorted to purchasing some sago stems from local growers while their own trees mature. This has led to a significant increase in the price of sago stems; when the company began operations three years ago, the price of a $110 \mathrm{~cm}$ 'tual' of sago was Rp. 15,000 (US\$1.50), presently it fetches nearly three times that much. The district government has requested that NSP refrain from purchasing sago stems from local producers so as not to undermine local mills operating in the district; they presently purchase any additional tual needed to meet production targets from farmers in the district of Siak on the Sumatran mainland.

Villagers in Kapau Baru, located at the main entrance of the NSP sago concession, are demanding compensation for sago groves they claim to have planted. How much of this they planted as paid employees of PT NSP's predecessor PT NTFP is unclear. Most men in the village work on the NSP plantation. Most likely the company will set aside a portion of the groves currently under preparation or already under cultivation as the livelihood plant' allocation for these local villagers.

While the NSP concession experiences the same sort of land compensation and labour disputes as plantations all across Indonesia, it has not encountered the same level of protest and contestation as the three acacia concessions discussed above. Local villagers' attitudes toward the operation are somewhat ambivalent; sago farmers we met are disdainful that the new interlopers do not consult with local growers to deploy 'local wisdom', but rely instead on agronomists from national universities. They expressed doubt as well that thinning sago stands and controlling water levels can increase production. Local mill owners speculate that PT NSP is manipulating the local price of tual, and fear that the company will attempt to establish a monopoly over sago harvesting and processing in the district. (This seems unlikely, as the NSP mill's processing capacity of 33 thousand tons represents only about 17 per cent of the district's current production.) Most fundamentally, it appears that the rural communities of Kepulauan Meranti recognise that a sago plantation does not represent the same sort of threat to the ecology of the islands that acacia plantations do.

If successful, this venture could present an important viable alternative model for forestry development in the Kepulauan Meranti district, as well as other peat swamp areas in Riau and elsewhere in Indonesia. Although NSP have not yet conducted any experiments to measure carbon emissions from their sago plantation, the fact that the peat is kept saturated precludes the sort of dehydration, oxidation and subsidence that occurs when peatlands are converted to either oil palm or acacia plantations (BAPPENAS 2009). Peat 're-wetting' is one of the major strategies proposed by the Indonesian National Council on Climate Change to reduce the country's GHG emissions (DNPI 2010). 
One alternative scenario that the district government has proposed to the Ministry of Forestry for the PT LUM concession is that it be converted instead into a sago plantation. Residents of surrounding villages have told us that they still intend that the concession be revoked altogether, or converted to community forest plantation (HTR) status, but that a sago concession would definitely be less objectionable than acacia.

\section{Conclusion}

The focus of this research was to investigate the intersection of two seemingly conflicting national policy imperatives - to grow Indonesia's economy through promotion of natural resource based industrial development, while at the same time trying to significantly reduce Indonesia's GHG emissions - as these play out 'on the ground'; i.e., to analyse the ways in which these policies and initiatives impact on particular local communities and ecosystems, and to try to understand the different ways that local communities respond to these changes. The Meranti islands are poised at the cutting edge of debates over Indonesia's climate change mitigation strategy and development approaches. The aggressive expansion of powerful Indonesian pulp and paper companies, particularly on carbon dense peatlands, is clearly at odds with Indonesian President Yudhoyono's 'progressive' and 'apparently sincere' statements on combating climate change, reducing deforestation and developing sustainable forestry (Butler 2012). The swamp-level viewpoint that informs these investigations reveals communities vulnerable to the impacts of both global climate change and global capitalistic development. It reveals as well an intimate glimpse of these same communities' 'ecologies of hope'.

We have shown that while powerful state and corporate actors in one of the world's most rapidly deforesting regions strongly shape the contours of socio-environmental change, social movements can and do have impacts, altering trajectories of change in particular local and regional landscapes. They may not entirely thwart capitalist expansion, but, as Rajan and Duncan (2013) argue, they can and do make incremental improvements to peoples' lives and environments. In the Meranti islands, concerted community action has delayed and possibly halted acacia concession activities on two islands, while communities and local government promote alternative economic activities and livelihood solutions. Their approaches and outcomes, as we show across three different islands, have different historical and social contingencies, and produce contrasting results. Combining everyday activities of localized resistance with scale-crossing alliances and networks of social movements, Meranti villagers and leaders, local politicians and government officials, smaller scale capitalists, and regional and national activists seek to moderate the strong political and economic forces affecting these islands, and to forge liveable compromises. Alternative pathways are appearing that suggest ways of managing these landscapes that are more environmentally sustainable and socially just.

\section{References:}

Alfons, J.B. and A.A. Rivaie (2011) 'Sagu Mendukung Ketahanan Pangan dalam Menghadapi Dampak Perubahan Iklim' ('Sago Supports Food Security in the Face of Climate Change'). Perspektif 10(2): 81-91.

Andiko, T. Batubara, E.B. Siregar, J. Suhendri, I. Harmain, A. Zazali, Wawan, A. Setiadi, I. Sukendar and K.S. Hut (2011) 'Laporan Tim Mediasi Penyelesaian Tuntutan Masyarakat Setempat Terhadap Ijin Usaha Pemanfaatan Hasil Hutan Kayu Pada Hutanam Tanaman (IUPHHK-HT) di Pulau Padang Kabupaten Kepulauan Meranti Provinsi Riau' ('Report of the Mediation Team on Settlement of Community Demands regarding the Industrial Forest Utilisation Permit (IUPHHK-HT) in Pulau Padang, Kabupaten Kepulauan Meranti, 
Province of Riau'). Jakarta: Ministry of Forestry, Republic of Indonesia.

Andriesse, J.P. (1988) Nature and Management of Tropical Peat Soils. FAO Soils Bulletin 59. Rome: FAO.

APRIL

(n.d.)

'About

APRIL'. http://www.aprilasia.com/, accessed 11 December 2012.

BAPPENAS (2009) 'Reducing Carbon Emissions from Indonesia's Peat Lands: Interim Report of a Multi-Disciplinary Study'. Jakarta: BAPPENAS.

Barnard, T.P. (2003) Multiple Centres of Authority: Society and Environment in Siak and Eastern Sumatra, 1674-1827. Leiden: KITLV Press.

Barr, C.M., A. Dermawan, H. Purnomo, and H. Komarudin (2010) Financial Governance and Indonesia's Reforestation Fund during the Soeharto and Post-Soeharto Periods, 1989-2009: A Political Economic Analysis of Lessons for REDD+. Occasional Paper no 52. Bogor, Indonesia: CIFOR.

Barr, C.M., I.A.P. Resosudarmo, A. Dermawan and J. McCarthy, eds. (2006) Decentralisation of Forest Administration in Indonesia: Implications for Forest Sustainability, Economic Development and Community Livelihoods. Bogor: CIFOR.

Berdikari Online (2013) 'Warga Pulau Padang Berhasil Cegah Operasi Alat Berat PT. RAPP' ('Residents of Pulau Padang Succeed in Preventing the Operation of PT RAPP Heavy Machinery'), 15 October 2013. http://www.berdikarionline.com/kab ar-rakyat/20131015/warga-pulaupadang-berhasil-cegah-operasi-alatberat-pt-rapp.html\#ixzz2nOkTTGjX ， accessed 14 December 2013.

Butler, R. (2012) 'Indonesia's Pulp and Paper Targets Incompatible with Green Growth Goals', Mongobay.com, 10 August 2012. http://news.mongabay.com/2012/08 10-barr-pulp-and-paperatbc.html\#crVEzk8XHkEjDXtV.99, accessed 11 December 2012.

Campbell, J. (2002) 'Differing Perspectives on Community Forestry in Indonesia', in C.J.P. Colfer and I.A.P. Resosudarmo, eds. Which Way Forward? People, Forests and Policymaking in Indonesia. Pp. 110-25. Singapore: Institute of Southeast Asian Studies.

Casson, A. (2002) 'A Forest of Palms: The Political Economy of Indonesia's Oil Palm Sub-sector and the Fate of the Forest', in C.J.P. Colfer and I.A.P. Resosudarmo, eds. Which Way Forward? People, Forests and Policymaking in Indonesia. Pp. 221-45. Singapore: Institute of Southeast Asian Studies.

Colfer, C.J.P. and I.A.P. Resosudarmo, eds. (2002) Which Way Forward? People, Forests and Policymaking in Indonesia. Washington, D.C.: Resources for the Future, Bogor: CIFOR \& Singapore: Institute of Southeast Asian Studies.

Corlett, R.T. (2009) The Ecology of Tropical East Asia. Oxford: Oxford University Press.

Djajanti, D. (2006) 'Managing forest with Community (PHBM) in Central Java: Promoting Equity in Access to NTFPs', in Mahanty, S., J. Fox, M. Nurse, P. Stephen and L. McLees, eds., Hanging in the Balance: Equity in CommunityBased Natural Resource Management in Asia. Pp. 63-82. Honolulu: RECOFTC and East-West Center.

DNPI (2011) DNPI Green Review on REDD+. Jakarta: Dewan Nasional Perubahan Iklim.

DNPI (2010) Indonesia's Greenhouse Gas Abatement Cost Curve. Jakarta: Dewan Nasional Perubahan Iklim.

Eyes on the Forest (2010) 'Peat Swamp Forest and Community Livelihoods Threatened by Planned Natural Forest Clearing by PT Lestari Unggul Makmur, a Pulpwood Plantation Company 
Associated to Asian Pacific Resources International Holdings Limited (APRIL) and Raja Garuda Mas (RMG), in Pulau Tebing Tinggi, Riau of Central Sumatra',

http://www.eyesontheforest.or.id/att ach/EoF_Investigative\%20Report\%20

PT\%20LUM_APRIL_Sep-

Oct_2009_Feb2010.pdf, accessed 11 December 2012.

Gillis, M. (1988) 'Indonesia: Public Policies, Resource Management, and the Tropical Forest', in M. Gillis and R. Repeto, eds., Public Policies and the Misuse of Forest Resources. New York: World Resources Institute.

Government of Indonesia (2011) 'Instruction of the President of the Republic of Indonesia, Number 10, 2011 regarding the Suspension of Granting New Licenses and Improvement of Natural Primary Forest and Peatland Governance'. Jakarta: Government of Indonesia.

Hecht, S. and A. Cockburn (1989) The Fate of the Forest: Developers, Destroyers and Defenders of the Amazon, New York: Verso.

Hooijer, A., S. Page, J.G. Canadell, M. Silvius, J. Kwadijk, $\mathrm{H}$ Wösten and J Jauhiainen (2010) 'Current and Future $\mathrm{CO}_{2}$ Emissions from Drained Peatlands in Southeast Asia', Biogeosciences 7: 110.

Jakarta Globe (2010) 'Sampoerna Agro Mulls Making Biofuel from Sago', Jakarta Globe $\quad 12 \quad$ April 2010. http://www.thejakartaglobe.com/bus iness/sampoerna-agro-mulls-makingbiofuel-from-sago/369093, accessed 11 December 2011.

Jauhiainen, J., A. Hooijer and S.E. Page (2012) 'Carbon Dioxide Emissions from an Acacia Plantation on Peatland in Sumatra, Indonesia', Biogeosciences 9: 617-30.

Joosten, H., M-L. Tapio-Biström and S. Tol, eds. (2012) Peatlands - Guidance for
Climate Change Mitigation through Conservation, Rehabilitation and Sustainable Use. Rome: FAO and Wetlands International.

Koh, L.P. and D.S. Wilcove (2008) 'Is Oil Palm Agriculture Really Destroying Tropical Biodiversity?' Conservation Letters xx: 1-5

Kompas.com (2011) 'Jahit Mulut, Perjuangan Warga Pulau Padang' ('Sewing their Lips, the Struggle of Pulau Padang Islanders'). 21 December 2011. http://megapolitan.kompas.com/read /2011/12/21/05373320/Jahit.Mulut.P erjuangan.Warga.Pulau.Padang, accessed 13 December 2013.

McCarthy, J.F. and M. Moeliono (2011) 'The Post-Authoritarian Politics of Agrarian and Forest Reform in Indonesia', in R. Robison, ed., Routledge Handbook of Southeast Asian Politics. Pp. 242-60. London: Routledge.

McClatchey, W., H.I. Manner and C.R. Elevitch (2006) 'Metroxylon amicarum, M. paulcoxii, M. sagu, M. salomonense, $M$. vitiense, and $M$. warburgii (Sago Palm)', Holualoa, Hawaii: Traditional Tree Initiative. http://www.traditionaltree.org/, accessed 11 December 2012.

Metroterkini.com (2013) 'Wan Abu Bakar Minta Izin RAPP Pulau Padang Dicabut' ('Wan Abu Bakar Requests that RAPP's Permit on Pulau Padang be Rescinded'). 03 November 2013. http://www.metroterkini.com/read7650-2013-11-03-wan-abu-bakarminta-izin-rapp-pulau-padangdicabut.html, accessed 13 December 2013.

Miettinen, J., C. Shi and S.C. Liew (2012) 'Two Decades of Destruction in Southeast Asia's Peat Swamp Forests', Frontiers in Ecology and the Environment 10(3): 124-28.

Ministry of Forestry (2009) 'Surat Keputusan Menteri Kehutanan Nomor : 327/Menhut-II/2009 tentang 
pemberian hak penguasaan Hutan Tanaman Industri Kepada Perusahaan PT Riau Andalan Pulp And Paper' ('Decision of the Minister of Forestry Number: 327/Menhut-II/2009 on Issuance of Industrial Forest Plantation Utilisation Permit to PT Riau Andalan Pulp and Paper'). Jakarta: Ministry of Forestry.

Page, S.E., J.O. Rieley and C.J. Banks (2011) 'Global and Regional Importance of the Tropical Peatland Carbon Pool', Global Change Biology 17: 798-818.

Peet R., P. Robbins and M. Watts (2011) Global Political Ecology. London: Routledge.

Peluso, N. (1992) Rich Forests, Poor People: Resource Control and Resistance in Java. Berkeley : University of California Press.

Peluso, N.L., S. Afiff and N.F. Rahman (2008) 'Claiming the Grounds for Reform: Agrarian and Environmental Movements in Indonesia', Journal of Agrarian Change 8(2-3): 377-407.

Polanyi, K. (1957) The Great Transformation, Boston: Beacon Press.

Rajan, S. R. and C.A.M. Duncan (2013) 'Ecologies of Hope: Environment, Technology and Habitation - Case Studies from the Intervenient Middle', Journal of Political Ecology, 20: 70-9.

Robbins, P. (2012) Political Ecology: A Critical Introduction, $2^{\text {nd }}$ Edition. Chichester, West Sussex; Malden, MA : J. Wiley \& Sons.

Ruddle, K., D. Johnson, P.K. Townsend and J.D. Rees (1978) Palm Sago: A Tropical Starch from Marginal Lands. Honolulu: East-West Centre, University Press of Hawaii.

Tan, K. (1983) The Swamp-Sago Industry in West Malaysia: A Study of the Sungei Batu Pahat Floodplain. Singapore: Institute of Southeast Asian Studies.

Thorburn, C. (2002) 'Regime Change Prospects for Community-Based
Resource Management in Post-New Order Indonesia', Society and Natural Resources 15:617-28.

Tim Pendukung Penyelamat Semenanjung Kampar (TP2SK) (2010) 'Pendapat Hukum (Legal Opinion)'. Typescript. Joint statement issued by Walhi Riau, Jikalahari, Scale-Up, Greenpeace SEA, KBH Riau, LBH Pekanbaru, Kaliptra Sumatera, Kabut Riau, Perkumpulan Elang, Mitra Insani, Bahtera Alam and TII Riau. Pekanbaru, 10 November 2010.

Ukirsari, N. (2012) 'Selatpanjang, Kota Persilangan Tionghoa-Melayu di Indonesia' ('Selatpanjang, a Hybrid Chinese-Melayu Town in Indonesia') National Geographic Indonesia 03 July 2012.

http://nationalgeographic.co.id/berita /2012/07/selatpanjang-kotapersilangan-tionghoa-melayu-diindonesia, accessed 11 December 2012.

Uryu, Y., C. Mott, N. Foead, K. Yulianto, A. Budiman, Setiabudi, F. Takakai, Nursamsu, Sunatro, E. Purastuti, N. Fadhli, C.M.B. Hutajulu, J. Jaenicke, R. Hatano, F. Siegert and M. Stüwe (2008) Deforestation, Forest Degradation, Biodiversity Loss and $\mathrm{CO}_{2}$ Emissions in Riau, Sumatra, Indonesia. WWF Indonesia Technical Report, Jakarta: Worldwide Fund for Nature.

Vleming, J.L.Jr. (1992) 'The Chinese Business Community in Netherlands India', in M.R. Fernando and D. Bulbeck, eds. Chinese Economic Activity in Netherlands India: Selected Translations from the Dutch. Pp. 90259. Singapore: ISEAS Press.

World Commission on Environment and Development (WCED) (1987) Our Common Future: Report of the World Commission on Environment and Development. Oxford: Oxford University Press. 